\title{
Research Strategies and Media Relations in Public Relations Practices
}

\author{
Rachmat Kriyantono \\ Universitas Brawijaya \\ Jalan Veteran Malang 65145 \\ *e-mail : rachmat_kr@ub.ac.id
}

\begin{abstract}
This study aims to describe the strategies of private and government public relations practitioners in research and media relations. Some literature states that the practice of public relations begins and ends with research and media relations is crucial to the success of the practice of public relations. In this era of openness, the quality of research and media relations is increasingly demanding high attention. The researcher formulated the assumption that public and private $P R$ have conducted research as the basis of their activities and media relations has been carried out on the principle of information disclosure. This study uses a qualitative method by conducting interviews with 32 public relations practitioners in East Java, and comes from universities, state-owned enterprises, and private companies. The results of this research are in the form of a proposition that practitioners have not given the focus of conducting research related to the quality of media relations, public relations universities have a tendency to make mass media as the main target while practitioners from private companies or state-owned enterprises tend to place leaders as the main public, and public relations practitioners tend to aim at reducing negative coverage as a media relations strategy rather than building long-term relationships. This research has contributed to the study of public relations in the Indonesian context related to the quality of research and media relations conducted by public relations practitioners.
\end{abstract}

Keywords: Agenda Building Information Subsidies, Media Relations, Public Relations, Public Information Openness, research

\section{ABSTRAK}

Penelitian ini bertujuan untuk menggambarkan strategi praktisi hubungan masyarakat dan swasta dalam penelitian dan hubungan media. Beberapa literatur menyatakan bahwa praktik Public Relations (PR) dimulai dan diakhiri dengan penelitian dan hubungan media sangat penting untuk keberhasilan praktik PR. Di era keterbukaan ini, kualitas penelitian dan hubungan media semakin menuntut perhatian tinggi. Para peneliti merumuskan asumsi bahwa $P R$ publik dan swasta telah melakukan penelitian sebagai dasar kegiatan mereka dan hubungan media telah dilakukan berdasarkan prinsip pengungkapan informasi. Penelitian ini menggunakan metode kualitatif dengan melakukan wawancara dengan 32 praktisi PR di Jawa Timur, dan berasal dari universitas, perusahaan milik negara, dan perusahaan swasta. Hasil penelitian ini berupa proposisi bahwa praktisi belum memberikan fokus melakukan penelitian terkait kualitas hubungan media, universitas humas cenderung menjadikan media massa sebagai target utama sedangkan praktisi dari perusahaan swasta atau badan usaha milik negara cenderung menempatkan pemimpin sebagai publik utama, dan praktisi humas cenderung bertujuan untuk mengurangi liputan negatif sebagai strategi hubungan media daripada membangun hubungan jangka panjang. Penelitian ini telah berkontribusi pada studi hubungan masyarakat dalam konteks Indonesia terkait dengan kualitas penelitian dan hubungan media yang dilakukan oleh praktisi hubungan masyarakat.

Kata kunci: Agenda Building Information Subsidies, Hubungan Masyarakat, Keterbukaan Informasi Publik, Relasi Media, Riset 


\section{Introduction}

Research serves to provide empirical information in the field and not from subjective construction so that research becomes the most important source of inspiration for Public relations to design its communication programs to be targeted, including media relations programs (Kriyantono, 2015). Media relations is very important to get optimal broadcasting from the media (Kriyantono, 2016), to find out public perceptions and analyze the effectiveness of planning, including sponsorships and community relations, and become the main opinion leader during a crisis (Jong, 2007). The importance of media relations is further emphasized by Ahmed (2006, p. 22) that "the development of a working relationship with the media in the face of a disaster is central to any crisis communication plan."

According to the Agenda BuildingInformation Subsidies Theory, Public relations is a provider of information for the media and that information can become a media agenda if it is published by the media (Cheng, 2014; Weaver et al, 2014). Public relations practitioners have a contribution in creating a media agenda that is acting as an influential news source (Robinson, 2014). The provision of this information is an interactive process between the communicator and the media, or called media relations (Kriyantono, 2019; Pfestsch \& Adam, 2011). Information subsidies have a role as a tool for carrying out media relations tactics by public relations practitioners to the media to achieve their goals.

Therefore, the researcher believe that the media relations strategy is closely related to research, that is, research is conducted to obtain quality information. The researcher considers that research and media relations are two very important activities for public relations practitioners. Research shows that $95 \%$ of journalists think that organizations need to proactively release information about the effects of the crisis rather than waiting for the media to report it (Robertson, 2012).

In addition, the urgency of research and media relations in the practice of public relations can be seen from the function of public relations embodied in the definitions of public relations by some scientists, such as "part of the management of communication between an organization and its public." (Grunig \& Todd Hunt, 1984, p. 173); "... building and maintaining mutual understanding between the organization and its public." (Tymson, Lazar \& Lazar, 2004, p.21). "The function helps organizations achieve their goals through effective communication and constructive relations." (Harrison, 2009, p. 1). "Management functions that build and maintain good and beneficial relationships with the public that affect organizational success or failure." (Cutlip, Center \& Broom, 2011, p. 6). Research makes public relations work based on scientific procedures rather than relying on intuition or guessing (Grunig \& Hunt, 1984).

The development of research in the practice of public relations in the $1990 \mathrm{~s}$ until now shows a tendency to increase to $24 \%$ compared to the 1980 s (Wimmer \& Dominick, 2011, p. 396). Stacks (2011) added that industrial companies in the US have increased the use of theory-based research on the impact of public relations activities.

However, despite experiencing good development, the researcher found quality and quantity constraints in research by public relations practitioners. Most public relations research is ordinary and informal, 
not scientific research and is inaccurate because it is done by public relations who have not been trained in research (Yin, Krishnan, \& Ean, 2012). The obstacle to research in practice is "the inability to conduct research and laziness, that is, preferring to use intuition and experience" (Cutlip, Center \& Broom, 2011, p.323).

In addition, the quantity of research is still low compared to the awareness of the importance of high research (Aggrey, 2009; Hon, 1998). Grunig (2008, pp. 28-32) mentions "there is a concern that the results of research will uncover the" sins "of Public Relations. 'Sin' here can be interpreted as deficiencies or failures of public relations. "fears the failure of the public relations program will be known to others.

The findings above are related to the findings of Grunig, Grunig, and Dozier (2008) that research constraints also arise from outside the practitioner (external), ie the management considers the research to be insignificant so as not to allocate sufficient funds for research activities. This attitude, according to Grunig et al (2008) is a reflection of organizational culture called asymmetry culture, a closed culture and not opening up to information from outside the organization, only looking at reality from the organization's glasses and not looking at reality from the public's perspective, considering efficiency and control over all costs is more important than the need for innovation so that it does not allocate sufficient funds for research activities.

How about in Indonesia? Do some of the research described above also occur in Indonesia? After conducting interviews with three public relations practitioners, Kriyantono (2015) found that public relations practitioners in Indonesia have understood and implemented research, although some still use simple methods with minimal availability of funds. It was also found that research needs were highly adapted to organizational culture, for example management's willingness to be open in responding to research results.

This study considers that the findings of Kriyantono (2015) are important to be followed up. Efforts should be made to expand the construction of research strategies and media relations in public relations practices, both private and government. Government PR has the same position as private PR. Referring to the Minister of Administrative and Bureaucratic Reform Regulation No. 33 and 31 of 2011, government public relations have the same function as private public relations, namely as communication management. Therefore, the function of research and media relations is also very important to be carried out by government public relations.

The importance of government public relations is conducting research and media relations as well because Indonesia has entered the era of democracy since the reform. This era of democracy demands the disclosure of public information because the public is increasingly critical and has easy access to information (Kriyantono, Destrity, Amrullah, \& Rakhmawati, 2017). Related to the universal principle of public relations from Ivy Lee, tell the truth (Grunig \& Hunt, 1984; Kriyantono, 2017), it can be said that public relations practitioners must regularly conduct research to obtain quality information.

Related to the relations of public relations functions based on ministerial regulations, literature, and public characters in the era of democracy described above, the researcher formulates research assumptions that public and private PR have conducted research as the basis of their activities and 
media relations have been carried out with the principle of information disclosure. The assumptions of this research need to be confirmed by formulating the following research questions: What are the strategies of private and government public relations practitioners in research and media relations?

\section{Literature review}

a. Building-Information Subsidies Agenda

The agenda building-information subsidies states that mass media are public representations to obtain information, therefore, whether or not requested, journalists will pursue information directly from public relations (Kriyantono, 2016; Sallot \& Johnson, 2006). Furthermore, the media needs organizations because there are events or information that must be conveyed to the public regarding their impact on the public (Furtuno, 2000), including in crises (Kriyantono \& McKenna, 2019).

Information-subsidies are activities that make public relations practitioners contribute to supporting the work of journalists. This contribution can be measured from two aspects, namely: providing information that is news worthy and building good media relations (Kriyantono, 2016; Zoch \& Supa, 2014). In addition, quality aspects of media relations are also needed in the information subsidy process. Good personal relations with journalists provide greater possibilities for public relations practitioners to get news coverage that is of interest to their organizations (Kriyantono, 2016; Lattimore, et al, 2011).

Grunig and Hon (1999) suggest a method for measuring a scale, namely: Controlling togetherness, public relations must understand that journalists have a high curiosity with information and are not prioritized which means that public relations cannot apply rigid rules to journalists (must be neat) shoes when covering the news, limit the time and motion of journalists); Trust, defined as the stage of trust of both parties and the willingness to open up to the other party, which consists of integrity (honest and fair organization), can be relied on (the organization will do what they say, so that community relations can prove the truth of the information they convey), competence (believe that organizations have the ability to do what they say); Satisfaction, the range in which each has pleasure from each other because they have positive expectations fulfilled, and profits are greater than what their prices are; Commitment, the extent to which each party believes that their relationship is worth maintaining; Communal relations, in terms of journalist relations and public relations are how to care for their respective professions and professionals in respecting the profession by not harassing the profession or not differentiating the media from other media.

Information-subsidies activities require the role of public relations to provide access for journalists to interview managers or leaders of the organization. According to Abdullah (2004, pp. 68-79), journalists prefer to interview people who have character: Having credibility, being sharp and analytical, rich in the latest data and information, having courage and social and moral responsibility, thinking coherently, consistent, easily accessible, broad-minded, and understands the work of journalists.

\section{b. Research in Public Relations Practices}

The research functions according Sulistyaningtyas (2010) are to find out the profile of the company, the determination of policies in the company, work programs, evaluation of activities, 
determination of strategies in facing business competition, solutions to corporate crises.

In addition, research also plays an important role in an organization. According to Treadwell and Treaadwell (2005), research conducted in organizations will provide an assessment of public relations and its strategy. In addition, the research also knows the mission, structure, and culture in an organization. Some literatures, such as Cutlip, Center, and Broom (2011) and Kriyantono (2015), mention that research has six main functions in public relations activities, including research serves as a means of confirming assumptions from management regarding public attitudes towards organizations; Clarifying research serves to assist management in analyzing issues that occur in the community associated with the organization; Understanding of issues is very useful in organizations in formulating programs that aim to improve the image of the organization. Finally, research guides practitioners in managing issues so as to minimize problems; Research functions to bring change to the organization when management has a position as the axis of the organization; Research is an activity carried out by public relations practitioners in the program. This is because research is the basis of the beginning and end of the program so that research is also referred to as an endless process. This statement is supported by Cutlip, Center and Broom (2011) that research is the beginning and end of all public relations activities; Research is a means to deepen the science of public relations both technicians and academics; and research serves to be a driving force for public relations practitioners in anticipating if problems arise.
In reality, public relations research is very unpopular. This can be seen from the symptoms found in many organizations that do not rely on pubic relations research in their programs, both annual and longterm programs. Supposedly, public relations practitioners use research to conduct surveillance, planning is based on research results that can be accounted for scientifically and objectively (Cutlip, Center, \& Broom, 2011).

Research is often the basis for evaluating programs. The results of these evaluations can lead to greater accountability and credibility with management (Wilcox and Cameron, 2009). Public relations practitioners regularly conduct research to evaluate and measure how public opinion, especially mass media (Kriyantono, 2014).

\section{Research Methods}

This study uses a qualitative method. "Qualitative methods are best understood as a data enhancers. When data is enhanced, it is possible to see key aspects of cases more clearly" (Neuman, 2006, p. 14). The researcher uses interviews as a data collection technique. Adopting Wimmer and Dominick (2011), the interview was chosen because the researcher intends to collect a life-world description of the interviewee in detail for the interpretation of meanings related to media relations and research strategies in the activities of informants in the field of public relations.

The researcher interviewed practitioners who were willing to participate in this study. Interviews were conducted between August and September 2015. Practitioners were also selected based on their ease of access in finding informants. There are 32 public relations practitioners who are willing to become participants, namely: public 
relations from Hotel Atria Malang, PT Badak Balikpapan, Brawijaya University, Indonesian Education University, Malang State University, Muhammadiyah University Malang, Bhayangkara University Surabaya, PT Semen Gresik, Jamsostek, Malang Regency Government, Malang State Islamic University, Alana Hotel Surabaya, Santika Premiere Hotel, Midtown Hotel Surabaya, Swiss-Bellin Surabaya, Bumi Surabaya Hotel, Mercure Hotel Surabaya, Novotel Hotel Surabaya, Atria Hotel \& Conference Malang, Pondok Jatim Park Hotel Malang, Sahid Montana 2 Malang Hotel, East Java Regional Police Department, Dr. Soetomo Surabaya, BPJS Employment in the East Java Region, PT. PLN Distribution of East Java, PT. Pelabuhan Indonesia III East Java, East Java Province Health Office, Airlangga University, Malang City Government Public Relations, Malang Regency Government, Surabaya Paragon Hotel, and Sidoarjo Regency Public Relations.

This collection uses an iterative technique, i.e. data analysis is carried out in conjunction with data collection (Kriyantono, 2014; Neuman, 2006). The data analysis technique used in the study was to use the interactive model of Miles and Huberman. The interactive model consists of three stages: 1) data collection 2) data condensation 3) data presentation and 4) Portrayal of Conclusions (Miles, Huberman \& Saldana, 2014). The data obtained were then categorized by the researcher based on the tendency of the interview data obtained from the 32 informants. For example the results of interviews about opinions related to media relations gave rise to the envelope money category.

\section{Result and Discussion}

a. Media as the main target public
The researcher asked the informants to rank the public they were targeting. In this study, the researcher limits public ranking to only three major types of public. Based on the data obtained by the research, the data shows that the mass media are the most publicly targeted public relations targets by informants. Airlangga University Public Relations admitted that the mass media, students, and the public became the target public. East Java Regional Police Public Relations who call journalists and the public as public targets. Public Relations Hospital. Dr. Soetomo Surabaya said that the mass media and the public were the target public. "The public being the main target of the media, patients are usually more handed over to customer services or nurses.

If some of the informants above mention that the target public is only external, it is different from the informants from State-Owned Enterprises (BUMN). In this study Public Relations from BUMN institutions mention other types of public that are not mentioned by some of the informants above. Public Relations of PT. Semen Indonesia targets the public to target shareholders, communities surrounding the company, mass media, and employees. Pelindo III Public Relations revealed that the target public is shareholders, shipping service users, the government, mass media, surrounding communities, and employees.

Conditions in BUMN also occur in private companies. Atria Hotel PR Malang said that the main target public was leadership or management, followed by mass media. PT Badak's Public Relations also puts the mass media under its leadership as the main target public. Another finding, in universities, both public and private, the researcher finds that the media were made the most important target of all publics. The 
University of Bhayangkara Surabaya Public Relations, for example, said that "the program for internal is creating internal media, creating a vent forum that bridges the interests of employees and management. Meanwhile, for external relations, more media relations."

The finding reinforces Waters, Tindall, and Morton's (2010) study that after surveying one hundred public relations practitioners in the US, the main skills needed by practitioners are writing and understanding media relations. Public relations and media are interdependent.

Understanding the relationship between public relations practitioners and journalists of paramount importance to practicing effective media relations (Supa \& Zoch, 2009). Understanding journalists' expectations is the most important factor in the media relations process (Supa \& Zoch, 2009).

Theoretically, the media need public relations to obtain effective, efficient, interesting and informative news material for the public while public relations requires journalists as audiences, mediators and gatekeepers to convey information and respond to the public's need to know and public relations is tasked with building a positive image (Kriyantono, 2017; Lattimore et al. 2010).

\section{b. Media relations and "the envelope culture"}

The researcher found several ways to establish media relations by public relations practitioners. Public Relations of the East Java Provincial Health Office said that besides holding regular meetings at the office, media relations were held by holding meetings outside the office as well as for lunch and chatting casually about health issues. While having lunch, reporters usually tell me everything they hear about the health department and the PR can immediately answer.

Public relations Pelindo III concretely said that the meeting place as an effort to establish good relations with the mass media is a mall in Surabaya. Public relations usually invite reporters to meet, eat, and talk in Surabaya Town Square. "Its function is that it can get me closer to them. And if we are close to journalists, for example, if there are negative issues, they will usually be confirmed directly to me. Well, if you don't know it, you won't. So the source of the answer was official from public relations." (Pelindo Public Relations).

The activity of treating mass media has become one of PR's favorite activities above. From the seven informants above, all of them provided free food and drinks to the mass media by starting from activities carried out within the organization such as the media center to conducting meetings outside the organization, for example at the mall. In addition to providing food and drinks for free, ways to build relationships in other ways are found in other informants. This joint holiday was carried out by the National Electric Company (PLN) Public Relations, which invited 30 journalists for a vacation to Batu, staying with family to bring Public Relations closer to the mass media. All accommodations are borne by the company.

The Public Relations Government of Malang Regency tells that it has done media relations by holding an annual gathering. "Journalists are invited to the gathering with the Regent as a form of friendship. Up to a more personal level, for example, I invited them personally to eat, or come to any event, for example, my birthday, stay at home or whatever." (Malang Public Relations). Malang Public Relations also claimed that it had never 
invited journalists on vacation. However, if there is coverage, there is little to replace gasoline for journalists. The above method is carried out with the reason to make reporters feel they must first confirm the PR when there are negative issues.

The mutually beneficial relationship between Public Relations practitioners and mass media is important to be formed by Public Relations practitioners because mass media is the most extraordinary and important channel for organizations to inform their stakeholders of messages (Supa, 2014). It can be said that the mass media should be an objective channel of information provider. However, the objectivity of mass media is not easy to obtain because of the practices carried out by a resource person towards mass media. Based on data on the ways and reasons of $P R$ in establishing good relations with the mass media, the researcher finds these methods fall into the category of envelope practice.

Envelopes or whatever their form is the desire of informants to influence journalists so that journalists will always experience confusion of determination, for example, free walks conducted by informants by inviting reporters to cover an event with facilities that allow journalists to come in at no expense (Rofiuddin, 2011). If the reporter has received a reward from the informant then he will feel frustrated pakewuh preaching negative things or the badness of the informant (Rofiuddin, 2011). Achmad (2012) mentions that shyness is ewuh pakewuh attitude which is one of the Javanese culture, that is worried that his behavior or words will offend others.

From the results of previous research, providing monetary gifts (envelope culture) also occur in other countries, such as South Korea and India. Kim (2018) conducted a survey of 342 practitioners and revealed that providing monetary gifts, performing formal responsibility, building informal relationships, receiving paid media coverage, and giving and accepting informal support were found to be significant sub-dimensions of media relations. This happened, according to Kim (2018), because paid media coverage showed a positive relationship with practitioners' public relations perceptions about the difficulties of increasing outputs of media relations. Varghese \& Rahman (2014) conducted research in India and found that communication technology made changes in the pattern of media relations in India. The similarities between Indonesia and Korea further strengthen the findings of Kriyantono and McKenna (2017) that although Asian communities have various cultures and local wisdoms, in general, they have common characteristics, such as looks at the world and universe as a single unit (an interconnected and interdependent whole) and focuses on wholeness and unity.

However, the researcher believes that giving money to this media seems to be reduced as a result of technological developments, from conventional media to online media. Online media causes reduced face-to-face interaction. This is confirmed by Zerfass, Vercic, and Wiesenberg (2016) research who found that there will be changes in the status of media relations in Europe while it reflects the upcoming media shift from mass mediated communication to own produced and delivered content by strategic communicators. Furthermore, new concepts are predicted, namely strategic mediatization, as a new practice supplementing and/or replacing old media relations.

c. Research in Media Relations 
The following is the meaning of research for public relations practitioners. Public relations practitioner Alana Hotel Surabaya said that the research was an analysis of the wants and needs of the audience and through the renivate.com system it was very easy for me. In addition, research can also analyze customer satisfaction. Pondok Jatim Park Hotel Malang defines research as analyzing the extent to which hotel developments in Batu and Malang are seen from the price, the number of rooms sold and the events they have made are successful or not.

In general, the researcher finds various meanings of research from interviews with practitioners. For practitioners, research is considered as research that analyzes audience needs and customer satisfaction, research that analyzes public interest, reviews of new-year's events, analyzes community development, and analyzes the market, the growth and the trend. That is, there are practitioners who think research needs to be done on all programs, but, there are those who are more focused on customer satisfaction.

Based on the research area, the researcher found that none of the practitioners conducted research related to media relations. Practitioners claim to conduct research to analyze the desires of customers and competitors through the renivate.com system, Analyze public needs, avoid mistakes in providing advertisement and reference events for next year, find out prices, activities and segmentation of hotels in Batu and Malang, observations about hotel competitors and analyzing the segmentation of hotel guests, through guest comments and communicating with hotel guests, and hotel guest ratings as evaluation material. That is, research has not been specifically analyzed the content of media coverage and how media needs.
For example, public relations practitioners at Pondok Jatim Park Hotel conduct research to determine the development of competitor hotels. "I did some research because I had to know the prices of all Malang and the same Batu hotels, how many rooms or all the rooms were full, what were their activities, segmentation of each hotel anywhere, so every hour, even every minute, I always carry out research."

The findings of this data need to be a consideration for the practice of public relations to conduct research related to media relations. The better the quality of the relationship between Public Relations and the media, the greater the chance that the information presented by the Public Relations will be published (Cutlip, Broom, $\&$ Center, 2011). The relationship between the two parties is also a symbiotic mutualism because Public Relations requires mass media as a means of disseminating information and information is needed by mass media from Public Relations, however, it must still consider the quality of information provision (Kriyantono, 2017).

In the context of public information disclosure, media relations must be based on the principle of providing information transparently, not based on the principle of preventing negative reporting. Most informants consider that media relations are more focused on closing media efforts to preach negative things. The data findings mention that the method that is often used is giving something that falls into the "envelope" category. Openness does not mean opening up information in its entirety but there are things that are sorted out so as not to damage the image of the organization but still be able to meet public information needs (Kriyantono, 2017). This means that when there is negative information or news that comes from an organization, not all 
information can be released by the Public Relations to explain or answer all public questions. This turns out according to Achmad (2012) in Indonesia, especially Javanese culture, assuming silent or closed people are considered good and still taboo, because self-disclosure is seen as arrogant, arrogant, arrogant, etc.

Research on the quality of media relations needs to be done by practitioners. This has been proven by Terek et al. (2015) that to increase organizational performances, companies should pay close attention to modern media, as well as to the presence of the CEO in the media. To increase business performance, companies should pay enough attention to both modern and traditional media, while the company's presence has an advantage over that of the CEO.

Research helps public relations practitioners understand the satisfaction and needs of journalists in the information-subsidies process. Kriyantono (2019) found satisfaction and needs of journalists when accessing the website as a means of information-subsidies. This research found that journalists need to provide information through an interactive website, not one-way communication.

According Waters, Tindall, and Morton (2010), it is important for public relations practitioners to adopt the emerging new era of media relations. As a result, by conducting research regarding the practices of media relations, public relations practitioners are able to examine how the social media landscape is changing and impacting the relationship between the media and public relations practitioners.

By conducting media relations research, public relations practitioners have ability to explore the impact of media relations efforts on news coverage
(Kiousis, Mitrook, Wu, \& Seltzer, 2006). Media coverage that stemmed from information subsidies was even found to influence policy issues that were not salient on either the media or the public's agenda (Waters, Tindall, \& Morton, 2010).

\section{d. Building propositions}

Based on the description of the data findings, the researcher can formulate propositions. This proposition is a typical finding of this research as an effort to develop studies in the future. The propositions are built as follows:

- Although placing the mass media as the main target in public relations activities, practitioners have not given the focus to do research related to the quality of media relations.

- The practitioners who come from tertiary institutions have a tendency to make mass media as the main target public while practitioners from private companies or state-owned enterprises tend to place their leaders as the main public.

- Public relations practitioners tend to aim at reducing negative coverage as a media relations strategy rather than building long-term relationships.

Adopting Cutlip, Center, and Broom (2011) and Kriyantono (2015), the researcher believes that there is still applied research in the practice of public relations in Indonesia, both for profit and non-profit organizations. These constraints, save in two factors: internal and external. Internal factors: The application of research in daily practice is very important by understanding Community relations to its function together with the space of work interaction. As the person responsible for planning and implementing communication management, public relations must be research oriented and 
have an understanding of the importance of research to support its work.

In addition, it is necessary to understand about communication theories and must have the provision of research application capabilities. Interestingly from a public relations executive as "opposing research in practice is the inability to conduct research and laziness, that is, preferring to use intuition and experience" (Cutlip, Center \& Broom, 2006, p. 323).

\section{Conclusion}

This research confirms the function of information subsidies as a very important function in public relations practice. This research reinforces that media relations needs to do research to understand the needs of the media, coupled with changes in communication technology in journalistic practice. Indonesia's local culture still seems to be a determining factor in how media relations are carried out, namely ewuh pakewuh which encourages the giving of money and goods to the media.

The research also confirms that there is no significantly different between type of organization (Government, business/private, and BUMN) regarding the strategy of research and media relations. It means that the findings tend to be generalized in any contexts of organizations, therefore, the results give important benefits for public relations in Indonesian contexts.

As limitation, the research cannot be evaporated in general contexts. Therefore, for further research, the researcher recommends a survey research to measure the effectiveness of media relations between public relations private institutions and government agencies. It is hoped that the findings of this research can stimulate public relations practitioners to improve the quality of their media relations. Furthermore, qualitative research needs to be done by interviewing PR practitioners and the media to explore the motives and opinions related to the media relations process so that obstacles and challenges can be found.

It is hoped that the findings of this current research contribute to enrich public relations research in Indonesia by evaluation the importance of research for the practices.

\section{Acknowledgement}

The researcher would like to thank Universitas Brawijaya for their support in the research and publication process.

\section{References}

Abdullah, A. (2004). Press relations, kiat berhubungan dengan media massa. Bandung: Remaja Rosdakarya.

Achmad, S.W. (2012). Wisdom van Java: mendedah nilai-nilai kearifan Jawa. Yogjakarta: AzNa Books.

Aggrey, K. (2009). Do public relations in Africa use research? A comparison of public and private organizations in Ghana. African Communications Research, 2(3), 397-418.

Ahmed, M. (2006). The principles \& practice of crisis management: The case of Brent Spar. New York: Palgrave McMillan.

Cheng, Z. (2014). An examination of the first- and second-level of agenda building with the image of China's president Xi Jinping in Xinhua and four U.S. news outlets (thesis). Syracuse University.

Cutlip, S. M., Center, A. H., \& Broom, G. M. (2011). Effective public relations (B. S. Tri Wibowo, Trans.). Jakarta: Kencana Prenada Media.

Grunig, J., \& Hunt, T. (1984). Managing public relations. California: Rinehart.

Harrison, K. (2009). Strategic public relations: A practical guide to success 
(5 ed.). Perth: Century Consulting Group.

Hon, L. C. \& Grunig, J. E. (1999). Guidelines measuring relationship in public relationship in public relations. Institute for Public Relations.

Hon, L. C. (1998). Demonstrating efectiveness in public relations: Goals, objectives, and evaluation. Journal of Public Relations Research, $10(2), 103-135$.

Jong, W. (2017). Meaning making by public leaders in times of crisis: An assessment. Public Relations Review, 43, 1025-1035.

Kim, S-Y. (2018). An exploratory study of transformed media relations dimensions after the implementation of an anti-graft law in Korea. Public Relations Review, 44(3), 363-373.

Kiousis, S., Mitrook, M., Wu, X., \& Seltzer, T. (2006). First- and second-level agenda-building and agenda-setting effects: Exploring the linkages among candidate news releases, media coverage, and public opinion during the 2002 Florida gubernatorial election. Journal of Public Relations Research, 18, 265285.

Kriyantono, R. (2019). Journalists' perceptions of government public relations websites as information subsidies in democracy era. The $6^{\text {th }}$ International SEARCH Conference Proceeding, Taylor's College Malaysia, 98-115.

Kriyantono, R., \& McKenna, B. (2019). Crisis response vs crisis cluster: A test of situational crisis communication theory on two crisis clusters in Indonesian public relations. Malaysian Journal of Communication, 35(1), 222-236.
Kriyantono, R., \& McKenna, B. (2017). Developing a Culturally-Relevant Public Relations Theory for Indonesia. Malaysian Journal of Communication, 33(1), 1-16.

Kriyantono, R., Destrity, N. A., Amrullah, A. A., \& Rakhmawati, F. Y. (2017). Management of public relations for supporting the anti-corruption national program in Indonesia. International Journal of Applied Business \& Economic Research, 15(20), 293-303.

Kriyantono, R. (2017). Teori public relations perspektif barat \& lokal: Aplikasi penelitian dan praktik. Jakarta: Kencana Prenada.

Kriyantono, R. (2016). Public relations writing. Jakarta: Prenada.

Kriyantono, R. (2015). Public relations, issues, \& crisis management: Pendekatan critical public relations, etnografi kritis \& kualitatif. Jakarta: Prenada.

Kriyantono, R. (2015). Konstruksi humas dalam tata kelola komunikasi lembaga pendidikan tinggi di era keterbukaan informasi publik. Jurnal Pekommas, 18(2), 117-126.

Lattimore, D., Baskin, O., Heiman, S. T., Toth, E. L. (2011). Public relations: the profession and the practice (3rd ed). Boston: McGraw Hill.

Pfetsch, B. \& Adam, S. (2011). Media agenda building in online and offline media-Comparing issues and countries. Reykjavik: University of Iceland, $6^{\text {th }}$ ECPR General Conference.

Robertson, J. (2012). Tell it all? Challenging crisis communications' rules. Public relations Journal, 6(1).

Robinson, K. (2014). Information subsidies and social media: The effect of news value presence on social media 
conversation. Virginia: Virginia Tech, Grunig PRIME Research Fellow.

Rofiuddin, M. (2011). Menelusuri praktik pemberian amplop kepada wartawan di Semarang (Tesis Program Magister). Diakses dari repositori institusional Universitas Diponegoro (38445)

Sallot, L.M., \& Johnson, E.A. (2006). Investigating relationship between journalists and public relations: working together to set, frame and build the public agenda, 1991-2004. Public Relations Review 32 (2006), 151-159

Stack, D. W. (2011). Primer of Public Relations Research. New York: The Guilford.

Supa, D. W., \& Zoch, L. M. (2009). Maximizing media relations through a better understanding of the public relations-journalist relationship: A quantitative analysis of changes over the past 23 years. Public Relations Journal, 3(4), 1-28.

Tymson, C., Lazar, P., \& Lazar, R. (2004). The new Australian and New Zealand Public relations manual. NSW: Tymson Communication.
Varghese, N., Rahman, N. A. A. (2014). The Practice and Effects of Corporate Media Relations in Chennai: Beyond Just Denials and Evolving? Public Relations Review, 155, 271-276.

Waters, R. D., Tindall, N. T. J., \& Morton, T. S. (2010). Media catching and the journalist-public relations practitioner relationship: How social media are changing the practice of media relations. Journal of Public Relations Research, 22(3), 241-264.

Weaver, D., McCombs, M, \& Shaw, D.L. (2014). Agenda-Setting research: Issues, attributes, and influences. London: Lawrence Erlbaum Associates.

Wilcox, D.L, Cameron, G.T. (2009). Public Relations: Strategies and Tactics. United States: Pearson.

Wimmer, R. D., \& Dominick, J.R. (2011). Mass media research: an introduction, ninth edition. Boston: Wadsworth.

Yin, P. L. P., Khrisnan, K., \& Lee, C.E.C. (2012). Evaluation research on public relations activities among public relations practitioners in Malaysian corporations: An exploratory study. SEARCH (Malaysia), 4(1), 41-60.

Zerfass, A., Vercic, D., \& Wiesenberg, M. (2016). The dawn of a new golden age for media relations? How PR professionals interact with the mass media and use new collaboration practices. Public Relations Review, 42(4), 499-508.

Zoch, L.M., \& Supa, D.W. (2014). Dictating the news: understanding newsworthiness from the journalist perspective. Public Relations Journal, 8(1). 